NBER WORKING PAPER SERIES

\author{
FLXED EXCHANGE RATES AS A \\ MEANS TO PRICE STABILITY: \\ WHAT HAVE WE LEARNED?
}

Lars E. O. Svensson

Working Paper No. 4504

\author{
NATIONAL BUREAU OF ECONOMYC RESEARCH \\ 1050 Massachusetts Avenue \\ Cambridge, MA 02138 \\ October, 1993
}

Given at the Eighth Annual Congress of the European Economic Association in Helsinki, August 27, 1993. The author especially thanks Andrew Rose for many discussions and comments. He also thanks Claes Berg, Bernard Dumas, Barry Eichengreen, Klas Eklund, Hary Flan, Peter Garber. Nils Gottfries, Lars Höngren, Assar Lindbeck, Hans Lindberg, Ragnar Lindgren, Maurice Obstfeld, Torsten Persson, and Charles Wyplosz for discussions and comments; Joakim Persson for research assistance; and Molly Ảkerlund for secretarial and editorial assistance. This paper is part of NBER's research program in Intemational Finance and Macroeconomics. Any opinions expressed are those of the author and not those of the National Bureau of Economic Research. 


\section{FIXED EXCHANGE RATES AS A \\ MEANS TO PRICE STABILITY: \\ WHAT HAVE WE LEARNED?}

\section{ABSTRACT}

The paper discusses what we have learned from last year's currency crises in ERM and the Nordic countries about fixed exchange rates as a means to achieve price stability. After discussing the explanations for the crises, the paper concludes that fixed exchange rates are not a shortcut to price stabilicy. Monetary stability and credibility have to be built at home and cannot easily be imported from abroad. Fixed exchange rates are more fragile and difficult to maintain than previously thought. They may even be in conflict with price stability, by inducing a procyclical destabilizing monetary policy, and by inducing an inflation bias. Building monetary credibility is even mote important with flexible exchange rates.

\section{Lars E. O. Svensson}

Institute for Intemational Economic Studies

Stockholm University

\$-106 91 Stockholm

SWEDEN

and NBER 
Alfred Marshall Lecture

\title{
Fixed Exchange Rates as a Means to Price Stability: What Have We Learned?
}

\author{
Lars E. O. Svensson
}

Institute for Intemational Economic Sludies, Stochiolm Unitersity

\section{Introduction}

Pegging the exchange rate to a stable low-inflation foreign currency can be seen as a means to achieve price stability in the domestic country. Pegging the exchange rate means that domestic monetary policy has to be focused solely on maintaining the exchange rate peg, which in turn implies implicit or explicit coordination of domestic and foreign monetary policy. Given this monetary roordination, price stability is supposed to be achieved through a simple disciplining mechanism: First, if a higher domestic than foreign inflation occurs, it leads to a domestic real exchange rate appreciation, that is, domestic goods become more expensive relative to foreign goods. This reduces the demand for domestic goods and induces a recession which reduces the domestic inflation subsequently to the same long-rin level as the foreign one. Second, wage- and price-setting behavior will to some extent anticipate these consequences of too high wage and price increases, which will make a higher domestic inflation less likely to occur in the first place. In this lecture I shall discuss what we have learned from the past year's events in Europe about fixed exchange rates as a means to achieve price stability.

- Given at the Eighth Annual Congress of the European Economic Association in Heisinki, August 27, 1993. The autbor especially thanks Andrew Rose for many discussions and comments. He also thanks Claes Berg, Bernard Dumas, Barry Eichengreen, Klas Eklund, Harry Flam, Peter Garber, Nils Gottíries, Lars Hörngren, Assar Lindbeck, Hans Lindberg, Ragnar Lindgren, Maurice Obstfeld, Torsten Persson, and Charles Wyplosz for discussions and comments; Joakim Persson for Iesearch assistance; and Molly Akerlund for secreterial and editorial assistance.

1 There are other reasons for bxed exchange rates, for instance to achieve a possible 
Let me start by recalling the conventional view in the spring of 1992 of the ERM, the Excharge Rate Mechanism, that is, the exchange rate cooperation within the European Monetary System. At that time the ERM was generally considered a successful way of importing German monetary stability into the rest of the ERM. Since its commencement in 1979 the ERM had achieved an impressive convergence of inflation and interest rates anoong its members. There had been no generai realignment after 1987. Realignment expectations had gradually decreased, and the system's credibility had increased (Frankel and Pbillps (1991), Syensson (1993), Rose and Svensson (1993)). The Maastricht Treaty abou: European Monetary Union had been signed in February 1992. Further convergence was anticipated, and the ERM was generally considered to be heading towards the EMU.

In the Nordic countries that were outside the ERM, the Fingish markka, the Norwegian krone and the Swedish krona were in the spring of 1992 each unilaterally pegged to the ecu, the European currency unit. Finland, Norway and Sweden had filed applications to join the European Community and thereby the ERM. The credibility of the Nordic exchange rate regimes differed markedly, though. Realignment expectations were low or nor-existent for the Norwegian krone, whereas they were higher for the Finnish markika and the Swedish krona. The markka and the krona had experienced several currency crises in the past few years, and the markka had been devalued by $12 \%$ in November 1991.2

An unusually dramatic year followed. By the late spring of 1993 eleven currencies had been attacked aftcgether, eight in the ERM and three in the Nordic countries outside the ERM. Of these, only three (the Belgian franc, the French franc and the Danish krone)

reduction of relative price variability in order to promote trade and general economic integration. These other reasons will not be discussed here.

2 See Lehmussaari, Suvanto and Vajanne (1993) and Hōrngren and Lindberg (1993) for details on the Finnish and Swedish experiences, respectively, including measures of sealignment expectations. Lindberg, Sōderlind and Syensson (1993) report realignment expectations for Sweden. Realignment expectations for Norway and Sweden are also reported in Section 5 below. 
had not been Hoated or devalued. By August 1993 the ERM bands for these had been widened to \pm 15 percent. The only currencies that had not been attacked were the Dutch guilder which remained within the narrow band relative the deutsche mark, and the Austrian schilling which maintained jts unilateral peg to the deutsche mark.

So, what have we learned from the past year's crises in the ERM and Nordic countries about fixed exchange rates as a means to price stability? In order to discuss this, I shall answer in turn the following questions: (1) What happened? (2) What are the explanations? (3) Was the September 1992 crisis anticipated? (4) What have we learned? Before doing that, let me state that $I$ do not claim any originality of the views and conclusions expressed here; most or all $I$ have to say is a synthethis and interpretation of the existing literature ${ }^{3}$

\section{What happened?}

Next I shall recall a few important events during during 1992 and 1993.1 On February 7, 1992, the Maastricht Treaty was signed, in an atmosphere of general optimism about the EMU's future. During the spring it was quiet in the ERM and for the Norwegian krone, whereas there were some realignment expectations for the Finwish markka and the Swedish krona. On June 2 the first Danish referendum took place, with a narrow majority for a "no" to EMU. Witb polls reporting increased support for a "no" in the French referendum to occur on September 20 and hence increased uncertainty about the future of EMU, market pressure mounled on some ERM currencies in August. Increased pressure on the Finnish markka forced it to be floated on September 8 . The Italian lira also devalued by 7 percent on the same day. On September 16, Black

3 The literature on last year's currency crises includes Bank for International Settlements (1993b), Committee of EC Governors (1993), Eichengreen and Wyplosz (1993), Goldstein et al (1993), Group of Ten (1993), Hōrngren and Lindberg (1993), IMF (1993), Portes (1993) and Rose and Svensson (1993).

4 See Group of Ten (1993, Annex V) for a more detailed chronology. 
Wednesday, the British pound was forced to float. Sveriges Riksbant (the Swedish centrai bank) made monetary history by raising the overnight marginal lending rate to 500 percent per year, thus maintaining the krona's parity in spite of strong speculative attacks. The lira fell through its ERM floor. On September 17 the lira was floated and the Spanish peseta devalued by 5 percent. On September 20 France voted "yes" to EMU by a very narrow majority. Pressure continued throughout September on the French franc, the Irish punt, the peseta and the Portuguese escudo. Sveriges Riksbank lowered interest rates to less extreme levels.

In November a new speculative attack on the Swedisb krona occurned. On November 19, after having lost foreign exchange reserves worth about $\$ 25$ bn in 6 days, the Riksbank let the krona float. Three days later the peseta and escudo were devalued by 6 percent. Pressure on the French franc, the Danish krone, the punt and the Norwegian krone continued into December. On December 10 the Norwegian krone was floated. The punt was eventually devalued by 10 percent on February 1, 1993. Pressure continned during the spring on the escudo and peseta, in March for the first time there was also pressure on the Belgian franc. On May 13 the escudo and peseta were devalued by 6.5 and 8 percent, respectively.

In July enormous pressure mounted on the Belgian franc, the Danish krone, the French franc, the escudo and the peseta. At a long meeting with ERM finance ministers and central banif governors that ended at 1.45 am on Monday morning, August 2, the bilateral exchange rate bandwidths in the ERM were increased to \pm 15 percent, except for the deutsche mark and guilder which by a separate German-Dutch agreement remained within the narrow band.

\section{What are the explanations?}

What are the explanations for these calamities? I will consider Eve main explanations that have been discussed in the literature, all of which I believe bave some explanatory 
power.

\subsection{Increased international capilal mobility}

During the last decade a highly integrated global capital market was created in which huge volumes of capital can be moved at short notice. Capital markets were deregulated and capital controls were removed as part of ECs 1992 Single Market Program. The turnover on the global foreign exchange market is estimated to have tripled between 1986 and 1992, and turnover adjusted for double-counting is estimated to have been about $\$ 1,000$ bn per day in the spring of 1992. As a comparison, the total foreign exchange reserves of the G-10 central banks amounted to about $\$ 400$ b.n. In August 1992 , on the eve of the September crisis, the foreign exchange reserves of Banque de France amounted to about $\$ 29$ bn. Central bank foreign exchange reserves, even if augmented by official borrowing, are clearly small in relation to the huge turnover on foreign exchange markets, suggesting that central bank foreign exchange interventions alone are unlikely to withhold speculative attacks. 5

A more specific phenomenon has been labelled "convergence trading." Many investors exploited the interest rate differentials between the low yield deutsche mark and high yield currencies like the lira and the Swedish krona, borrowing in deutsche mark and investing in lira and krona. After the September crisis investors have reported in interviews that they did this mostly expecting further convergence and disappearance of the interest rate differentials, in which case they would make a capital gain. Alternatively, in case a realignment would appear imminent, they expected to be able to close their open positions, for instance by hedging their investments on the forward foreign exchange market, receiving help by central banks intervening to postpone the realignment. As a result, a large volume of capital was invested in the high-interest currencies, capital that might quickly move out in case of increasing realignment expectations.

\footnotetext{
5 See Bank for International Settlement (1993a) and Goldstein et al (1993) for details. 6 See Group of Ten (1993) and Goldstein et al (1993).
} 
The existence of initial long positions from convergence trade is not a necessary condition for a speculative attack on a currency, though. A speculative attack can be made from an initial closed position via short selling of a currency on the forward foreign exchange market, or any other derivative market.

\subsection{Real exchange rate divergence from nominal shocks to prices and wages}

For severai years some tension built up in the ERM and in the Nordic countries because real exchange rates diverged because of too high domestic inflation in some countries. This inflation can be seen as the result of nominal shocks to wages and prices, in turn caused by a combination of lack of monetary credibility, loose fiscal policy, and an inflation bias in the wage formation process. Considerable real exchange rate appreciation relative to the deutsche mark is apparent in Figure $l$ for Italy, Portugal and Spain within the ERM, and for Finland and Sweden within the Nordic countries. The resulting tension would eventually have to be resolved, by lower inflation in these countries or by exchange rate depreciation. ${ }^{7}$

\section{S Required real exchange rate adjustment from asymmetric real shocks}

Asymmetric real shocks, that is, real shocks that hit one country but not the others, may require a real exchange rate adjustment, a change in the price of the country's goods relative to other countries' goods. Such real exchange rate adjustment may create problems in a fixed exchange rate regime, whether achieved via a nominal realignment or via different inlation rates across countries. An expected nominal realignment may juduce a speculative attack, and may also create expectations of future realigments. Adjustment through different inflation rates may be too slow, too inflationary or, if rapid disinfation or even deflation is required, too painful.

German unification is the most obvious asymmetric real shock that has hit the ERM

7 The Balassa-Samuelson effect, that the price level terds to be higher in high-income countries because the price of nontraded goods is higher, may perhaps explain some of the real appreciation of Portugal and Spain, since these countries were growing rapidly during this period. 
the last few years. The unification lead to a German fiscal expansion, since German taxes were not sufficiently raised to balance the increased public expenditure. This increased demand for German goods and services, which should result in German goods and services becoming more expensive relative to non-German goods and services. That is, an initial real appreciation of the deutsche mark was required. This was required when several ERM currencies instead of real depreciation experienced a real appreciation towards the deutsche mark, as we saw above.

A real deutsche mark appreciation can be achieved in three ways, not mutually exclusive. The first way is a nominal revaluation of the deutsche mark. This was suggested by Bundesbank at an early stage, but blocked by France. The second way is higher German inflation. Bundesbank allowed German inflation to increase somewhat, but not by very much in order to avoid endangering Germany's price stability goal. There remained the third way, lower inflation outside Germany. This required a tight monetary policy in the European countries outside Germany, in conflict with a deepening recession and increasing unemployment in some of the countries. Eventually this third way failed, and in the end a nominal appreciation of the deutsche mark was achieved anyhow. It appears that an early deutsche mark revaluation as suggested by Bundesbank would have been the optimal response, and that in that case perhaps ERM could have been saved for several years. The route to a deutsche mark revaluation turned out to be long and painful, indeed.

I In the longer run, the real deutsche mark rate should depreciate back at least to its initial level, perbaps further, as output eventually increases in East Germany.

9 In my view Bundesbank has suffered completely unwarranted criticism for itg insistance on maintaining German price stability and its refusal to give in to demands from all over Europe to loosen its monetary policy. Critics seem to have forgotten that German price stability was in fact the nominal anchor of the ERM, that Bundesbank has no reason to compromise on German price stability because other ERM countries refuses a nominal deutschemark revalutation, that Bundesbank was against the generous conversion of East German marks, and that Bundesbank was in favor of increasing German taxes more in order to pay for the unification. Bundesbank's position instead appears fully consistent and responsible. 
A second example of a real asymmetric shock is the Finnish loss of exports to the former Soviet Union. During 1991 alone Finland's export to the Soviet Union dropped from $13 \%$ to $5 \%$ of total exports (Sōderstrōm (1993)). Such a fall in the demand for Finnish goods should require Finnish goods becoming cheaper relative to other countries' goods, that is, real depreciation of the marksa is needed. With a fixed exchange rate, this had to be achieved through less inflation, or even deflation. With downward price- and wage rigidity this proved too difficult, and a nominal devaluation of the markka was undertaken in November 1991. This proved insufficient and the markka further depreciated after it was floated in September 1992.

A third example is the volatility of Swedish consumption at the end of the 1980 s and eariy 1990s. The thick line in Figure 2 shows the Swedish savings ratio from 1982 to 1992. After having been about 2 percent (of household disposable income) it dropped to minus 6 percent between 1986 and 1989.10 This implied a big increase in consumption demand, most of which would fall on Swedish goods and services, and it required a real appreciation of the krona. With a fixed exchange rate, this could only be achieved through inflation. The thin line in the Figure shows the inflation rate- Inflation indeed went up and reached 10 percent per year in 1990.

By then, however, the savings ratio increased dramatically to reach 8 percent in 1992 , corresponding to a dramatic fall in consumption." Such a collapse in consumption demand requires a real depreciation. With a fixed exchange rate that has to be achieved by low inflation, or even deflation. Inflation indeed fell to almost 2 percent per year in 1992. A further real depreciation was achieved by floating the krona in November 1992.

10 Among the reasons for this consumption boom is the deregulation of the Swedish credit market while income taxation favoured borrowing, resultigg in low after-tax real interest rates.

11 Among the possible reasons for the increase in the savings ratio are a tax reform that favored saving, uncertainty about future pension payments due to rapidly increasing budget deficit, incresed uncertainty about future employment prospects, and increased after-tax real interest rates. 


\subsection{Expectctions of a more expansionary monetary policy after a collapse}

A country may pursue a tight monetary policy and defend its fixed exchange rate in spite of domestic recession, high unemployment and substancial short-run costs for several reasons. One reason may be a determination not to lose hard-won improvements in exchange rate credibility and prospects of future monetary stability. Another reason may be to fulfill the EMU convergence criteria and eventually reap the long term benefits of entering the EMU (not baving had a realignment within two years is one of the criteria for entering EMU in the Mastricht Treaty). As long as the long-run benefits outweigh the short-run costs it makes sense to defend the exchange rate.

However, if a realignment would be forced upon the country, monetary credibility and prospects of future price stability would be diminished, as would the probability of being accepted into the EMU. Hence the long-run benefits from the tight monetary policy would be less, and if they fall below the short-run costs of the policy, it is rational to shift to a more expansionary monetary policy. Put differently, if one's virtue is lost, one might as well enjoy oneself.

In a situation like this mutiple equilibria are possible.12 In one equilibrium no speculative attack occurs, the exchange rate remains fixed, and monetary policy remains tight. In the other equilibrium a speculative attack occurs, a realignment or a free float follows, and monetary policy switches to become more expansionary, ex post rationalizing the speculative attack. The Danish "no" and the wncertainty about the French referendum contributed to make the EMU more uncertain and to make the second equilibrium more likely. The multiple-equilibria explanation seems relevant for' Italy, Britain, and perbaps France. Among the Nordic countries it appears to apply for Finland and Sweden, where it is clear that more expansionary monetary policies in response to domestic recessions have been pursued after the collapse of their fixed exchange rates.

12 Eichergreen and Wyplosz (1993) extend on the multiple-equilibria explanation for the crises in ERM. Multiple equilibria in models of speculative attacks have previously been examined by Flood and Garber (1984) and Obstfeld (1986). 


\subsection{Problems with the tactical defense againgt spectative attack}

The tactical defense against speculative attacks tumed out to be more difficult than anticipated. Central banks mainly used two methods of defense, sterilized interventions (interventions without interest rate increases) and interest rate increases (non-sterilized interventions). 13

Slerilized interyentions were very large but still ineffient. That they were inefrcient is actrally not surprising given the empirical evidence in the literature that sterilized interventions indced have little effect on exchange rates. As an example of the magnitude of interventions, recall that Banque de France bad foreign exchange reserves worth $\$ 29$ bn in August 1992. Banque de France interventions at previous ERM crises had some days reached $\$ 1.5$ bn. In the September crises, interventions were reported to be aboul 5 times bigger some days, \$5-9 bn (Goldstein et al (1993)). On July 29, 1993, Banque de France was estimated to have intervened for more than $\$ 27$ bn (Financial Times, August 13, 1993).

Central banks can borrow foreign currency to increase their reserves. This is risky, though, since the bortowing central bank will suffer a capital loss if a realignment eventually occurs. In the ERM the accounting is in terms of ecu: this means that both borrower and lender (rend Bundesbank) loses in the case of an ERM realignment, since the ecu is an average of the EC currencies. Such capital losses can easily wipe out a central bank's own capital, which is usually a modest share of its balance sheet, and pot the bank in the embarrassing position of having to ask its government of parliament to put up more capital.

Large interventions eventually become difficalt to sterilize, and tend to turn into nonsterilized interventions, that is, interest rate changes. For Bundesbank, this means interest rate decreases, which may be in conflict with German price stability. Therefore, Bundesbank bas good reasons to resist too large juterventions, and there is evidence that

:J Trland, Portugal and Spain also used temporary capital controls. 
Bundesbank's stipport of ERM currencies was selective and limited, even though ERM rules stipulate that interventions shall be unlimited. 14

This brings me to the other main type of defense, interest rates increases for the weak currency. The idea with interest rate increases is to increase the opportunity cost of speculating and in the limit make speculators indifferent between keeping their investment in the weak currency and getting out. The Swedish experience showed that very high interest rates may be needed: expectations of a 10 percent devaluation in one week with probability one corresponds to an interest rate differential of 520 percent per year. Very high short interest tates are costly for several reasons, and the costs vary depending upon the institutional setup and economic conditions in each country. A fragile financial sector may suffer severe disruptions. The speed at which high interest rates are transmitted to households and firms vary across countries. Sweden with mostly fixed rate mortgages has slower transmission than Britain with mostly floating rate mortgages. The Italian public deficit is Enanced with large treasury bill auclions, auctions that may turn sour with too much interest rate volatility. A domestic recession with high unemployment makes the tolerance for interest rate hikes less and may quickly erode the political support for defending the exchange rate. This is particularly problematic when the central bank is not independent and monetary policy is in the bands of the government, for instance in Britain. "Which will fall first, the pound or the goverment?" was then a relevant question, as some have observed.

Once some currencies were devalued or depreciated through loating, the crisis worsened as the pressure then was concentraled on the remaining currencies. One reason for this is that deteriorating international competitiveness because competitors' currencies are being depreciated makes maintaining a fixed rate more costly for the remaining

14 See Eichengreen and Wyplosz (1993) for written evidence prior to the September crisis that Bundesbank and the German government felt committed to ERM interventions only in so far as these did not jeopardiae German price stability. 
currencies. 15

\section{Was the September crisis anticipated?}

Next I would like to discuss whether the September crisis 1992 came as a surprise or whether it was anticipated. Here I rely on joint work with Andrew Rose (Rose and Svensson (1993)). First, with regard to the Finnish markka and the Swedish krona, there were clear realignment expectations and several previous currency crises, so the eventual collapse of their fixed rates in September and November was certainly anticipated (Lehmussaari, Suvanto and Vajanne (1983) and Lindberg, Sōderlind and Svensson (1993)). What about the ERM?

There were ample warnings from some economists about mounting problems for the ERM, both about its vulnerability to increased capital mobility and about the required real appreciation of the deutsche mark.10 Some economists thererore displayed considerable foresight. What about policymakers and markets?

That policymakers lacked foresight is evident from their failure to revalue the deutsche mark in spite of the good reasons to do so. What about markets? The evidence shows that marices did not anticipate the ERM September crisis, except ather late in August. Figure 3 shows 95 percent confidence intervals for estimated realignment

15 A sometimes mentionend sixth explanation for the September crisis is the weak dollar. The dollar reached a new historic low towards the deutsche mark on September 2, 1992 (1.387 DM/USD). A weak dollar has previously been correlated with tension in the ERM. As reasons for suck tensions has been mentioned that trade shares with the US vary across EFM countries, the trade share being highest for Britain. ERM countries are therefore affected differently from export difficulties to the US. A general ERM export slowdown to the US would also hit already weak economies harder. It has frequently been suggested that deutsche marks are a closer substitute to dollars than othet ERM currenges, and that investors leaving the weak dollar would invest in deutsche mark rather than other ERM currencies. I remain wnconvinced that a weak dollar was a decisive factor in the September crises, except in so far as it reflects a relative tight German monetary policy, and believe that the main explanations are internal rather than external. Also, since the dollar was strengthened considerably by the summer of 1993, it cannot explain the July crisis.

16 There were for instance many both technical and non-technical publications from the CEPR with such warnings, as documented by Portes (1993). 
expectations relative to the deutsche mark for the the six original non-German ERM currencies, as well as the Austrian schilling, the Norwegian krone and the Swedish krona. The period extends through the September crisis. Vertical bars denote realignments. The estimates bave been constructed according to the "drift-adjustment" method, that is, by adjusting the interest rate differentials relative to the deutsche mark for expected exchange rate movements within the band. The resulting expected rates of realignment can be interpreted as the product of the probability per unit of time and the expected size of a realignment in case a realignmeni occurs. The estimates are done or 3-month interest rates, hence they concern expected realignments within a 3 -month horizon. Estimates of 1-month and 12-month horizons give the same impression. IT

The hypothesis of zero realignment expectations can be tested by examining whether the horizonial line corresponding to zero realignment expectations falls within the confidence interval. We see in Figure 3 that for the six ERM currencies realignment expectations decreased over the years and that they were small and insignificant in the spring of 1992. This was also the case for the Austrian schilling and the Norwegian krone, whereas there were some realignment expectations for the Swedish krona. Figure \& shows the period from January 1991 through October 1992 in greater detail. The Danish referendum on June 2 and Black Wednesday, September 16, 1992, are marked by vertical bars. We see that realignment expectations increased and became significant for Italy in July, whereas [or the other countries they remained insignificant well into August. As concluded in Rose and Svensson (1993), market participants did not anticipate the crisis until well into August, except for Italy, ia

17 The same impression results from an application of the "simplest test of target zone credibility" in Eichengreen and Wyplosz (1993), where 12-month forward exchange rates are plotied relative to the ERM bands.

18 For the multiple-equilibria explanation referred to above, no anticipation of the crisis implies attaching zero probability to the equilibrium with a speculative at tack. 


\section{What have we learued?}

What have we then learned from this dramalic period about fxed exchange rates as a means to achieve price stability?

\subsection{Fized exchange rates are fragile}

I think we shonid acknowledge that fixed exchange rates have proved to be much more fragite and difficul to maintain than many of us thought. The increased international capital mobility has made them more vulnerable to speculative attack. Fundamentals need to converge much more to avoid real exchange rate divergence or, put differently, the tolerance for diverging fundamentals is moch Fess. Asymmetric real shocks that require real exchange rate adjustment cause problews. The effective tactical defense against speculative attack turned out to be more difficalt than anticipated. It has mainly to be done by interest rate increases. These may need to be large and costly, the precise costs varying with the institutional and economic conditions in each conntry; often the costs are much too high for the defence of the exchange ratge to be credible.

\subsection{Fised exchange rates may be in confict with price siability}

Even if fixed exchange rates could be maintained, they are less efficient in achieving price stability than we thought. They may even be in conflict with and hence detrimental to price stability.

First, the disciplining mechanism of a fixed exchange rate, that higher inflation brings a real appreciation which brings a recession which lowers inflation, secms to trork too slowly. Fixed exchange rates bave not been credible enongh to modify wage and price setting and prevent nominal shocks and too high inflation in some countries. The resulting real exchange rate appreciation has lasted for several years, as demonstrated by Figure 1. Instead of a quick return to equilibrium, tension has continued to build up so much that an eventual lowering of inflation has not been enough to restore equilibrium; depreciation by a devaluation or a float has resulted instead.

Second, a fixed exchange rate may result in procycical, hence destabilizing, monetary 
policy. The argument goes like this. Suppose a boom starts, because of an increase in consumption, loose fiscal policy, or some other reason. The boom results in higher inflation. Suppose the fixed exchange rate is credible. Then with free capital mobility the nominal interest rate is given from abroad. When inflation increases, the realinterest rate falls, and monetary policy in that sense become expansionary and contributes to the initial boom. This is the well-known critique of the ERM that has already been formulated by Walters (1986). I believe that it has to be taken more seriously than before, and also that it should be taken one step further, namely to consider realignment expectations:

The central bank may contemplate a revaluation of the domestic currency in order to dampen the initial boom. Suppose expectations of a revaluation arises. Then an incipient capital inflow in order to capture the possible capital gain from a revaluation will tend to appreciate the exchange rate, and the central bank will have to stop the capital inflow by creating an unfaworable interest rate differential relative to the foreign currency and hence lower the domestic interest rate. This lowers the real interest rate further, and makes monetary policy even mōre expansionary.

The argument is of course symmetric for the recession case: An initial recession lowers the inflation rate, which with a given domestic interest rate increases the real interest rate and makes monetary policy contractionary. Devaluation expectations forces the central bank to increase the interest rate which implies an even higher real interest rate and an even wore contractionary monetary policy, is 20

Figure 5 gives an example of this phenomenon for Sweden. The intermediately thick curve shows the unemployment rate from 1992 into 1993. The economy experienced a boom after 1986, from the increase in consumption illustrated in Figure 1. This shows up

19 Rigorous modelling of the Walters critique requires eitber inflation inertia as in Giavazzo and Spaventa (1990) or some inconsistency between inlation expectations in financial markets and labor markets as in Miller and Sutherland (1991).

20 Note that this is counter to the standard textbook result for monetary policy in a fixed exchange rate, aamely that monetary policy is neutral and has no effect on aggregate demand. 
in unemployment steadily falling until reaching 1.4 percent in 1989 . This resulted in inflation picking up after 1986, as shown by the thin line, the inflation rate. At the time realignment expectations were rather low (see Figure 2). Domestic nominal interest rates were given from abroad and rather moderate. With the increased inflation, real interest rates becarne ratber low. The thick line shows the 12 -month ex post real interest rate. We see that it became very low at the peak of the boom in 1989, and presumably contributed to the boom. After 1990 a quickly deepening recession set in. Intlation came down dramatically in 1991. Furthermore, increased devaluation expectations lead to increased nominal interest rates. As a result the 12 month ex post real interest rate became very high and went from less than a half percent per year to 10 percent per year in less than two years, certainly contributing to the deepening recession.2l

This tendency for monetary policy to be procyclical implies that the demand on fiscal policy to stabilize the economy increases. Given the repeatedly demonstrated difficulty of conducting an appropriate fiscal policy, it scems realistic to doubt that liscal policy can [ulfil] these demands.

Third, real exchange rate variability from real shocks, combined with downward price and wage rigidity, may result in an inflation bias with fixed exchange rales, a bias away from price stability. Consider first unilateral regimes. A required real appreciation is easy to achieve: a bit of inflation will do it, as in the Swedish boom at the end of the 1980 's. A real depreciation with fixed exchange rates requires disinfation or even deflation. With downward price and wage rigidity this will be difficult to achieve, and may end with a cepreciation through a devaluation or a float instead, as the Swedish consumption collapse is the early 1990's or the Finnish loss of export to the former Soviet

21 Instead of the crude ex post real interest rate in Figure 5, an ex ante real interest rate can be computed with the help of survey data of households inflation expectations. This ex ante real irterest rate gives the same impression as the ex post real interest rate. (In the diagram the ex post real interest rate from January 1989 to January 1990 is plotted on January 1989 , whereas the ex post inflation rate for the same 12 months is ploted on January 1990.) 
Union shows. This may create an inllation bias and make price stability difficult to achieve.

In a multilateral regime like the ERM any real exchange rate adjustment is easy, as long as it is done by inflating the strong currency. The German unification provides an example. The French resistance to a nominal realignment of the deutsche mark and insistence on the Bundesbank lowering interest rates can be interpreted as an attempt to achieve the real apprecialion of the deutsche mark by German inflation. This method of handling required exchange rate adjustment would certainly have increased average ERM inllation, in addition to weakening ERM's anchor currency, the deutsche mark. 92

\subsection{Fixed exchange rates are in general no shortcut to credible price stability}

This brings me to my main conclusion: Fixed exchange rates are in general no shortcut to credible price stability. This does not deny that fixed exchange rates may achieve considerable temporary success. Twelve years of substantial inflation convergence in the ERM certainly appears impressive. But in the longer run fixed exchange rates are much less effective in achieving price stability. Monetary stability and credibility are not easily imported, they must be built at home.

The way to build credibility at home has been extensively discussed. It has several components. One component is an institutional reform making the price stability the goal of monetary policy and increasing the independence of the central bank. To build credibility, an isstitutional reform needs to have three parts, namely to put price stability in the central bank charter, to give the central bank sufficient independence so that it can fulfil the goal of price stability, and to make the central bank accountable for fulfilling its

22 The inflation bias for fixed exchange rates is counter to the previously mentioned "ratchet elfect" in Crockett and Goldstein (1976), who at tribute the ratchet effect to Mundell, Laffer and Wanniski. According to their ratchel effect there would be an inflation bias with flexible exchange rates because prices of traded goods in domestic currency would easily rise when the exchange rate depreciates, whereas they would fall less when the exchange rate appreciates. However, empitical estimates reported by Crockett and Goldstein failed to lind any inflation bias for lexible exchange rates compared to fixed rates, suggesting that things other than the exchange rate regime are crucial to price stability. 
goal. A second component is a fiscal policy consistent with price stability. A third is improvement in the functioning of labor markets so wage setting may be sufficientiy nexible to be consistent with price stability and full employment.

A fourth component is political support for a price stability policy. There seems to be a danger of a vicious circle of low credibility for initiating a price stability policy and low political support for price stability, Low initial credibility and high inflation expectations imply that wages, prices and interest rates are set incorporating expected inflation. Pursuing a price stability policy, resulting in lower than expected inflation, is then costly jn terms of output, employment and ex post real interest rates. This makes a shift to a policy of price stability unpopular, which in turn reduces the credibility of such a policy sbift.

Breaking such a vicious circle may not be easy. To do so, public and policy makers geed to be convinced that price stability is desirable, that institutional reform is necessary for credibility, and policy makers need to purbue a fiscal policy consistent with price stabiity. It is good news that moves seem to be underway in France, Italy, Spain and Portugal to reform the status of the central bank.

\subsection{With fexible erchange rate it is even more important to build monetary credibility}

What have we learned about monetary policy with a fexible exchange rate from the period after the fail of the bxed exchange rate regimes? The previous nominal anchor, the fixed exchange rate, bas been lost. A new nominal anchor is needed, and there are very strong arguments to provide that new anchor by a price stability goal for monetary policy: A low and stable inflation provides the best environment for efficient resource allocation and growth, and it prevents the arbitrary and unfaiz wealth redistributions associated with bigh and variable inflation.

In the new situation with flexible exchange rates, there is pressure for inflation and exchange rate depreciation from many special interest groups, monetary credibility is damaged, there is more uncertainty about future monetary policy, and there is a risk for a 
return to a sustained high infation. In this unstable situation, building credibility for a price stability policy is even more important than previously.

Let me only point out one thing that is sometimes forgotten. Price stability does not exclude using monetary policy for short-run stabilization. First, there is some degree of automatic stabilizing of aggregate demand shocks in a monetary policy that aims at price stability, namely wjth tight monetary policy in booms to prevent infation and loose policy in recessions to prevent deflation. Second, with long-run credibility for a price stability policy, there is more scope to use monetary policy for short-run stabilization (Bernanke and Mishkin (1992)). Without long-run credibility a short-run monetary expansion may be interpreted as the beginning of a new period of sustained inflation. Then inflation expectations rise, long interest rates go up, nominal prices and wages increase, and the positive effect on output and employment is smaller and more short-lived. With long-run credibility, a short-run monetary expansion does not increase inflation expectations, prices and wages as much, and the effect on output and employment is larger.

It is instructive to contrast Germany and the US with Britain and Sweden. Germany and the US seem to have achieved long-run credibility for their monetary policy which shows up as relatively low long interest rates and low long-run inflation expectations. This altows considerable short-run scope for monetary policy. For instance, the US could in the 1990-93 recession pursue a very expansionary monetary policy with very low short interes: rates without getting high long interest rates and high long-run inlation expectations.

In Britain and Sweden, in contrast, there is less long-run credibility which shows up in higher long interest rates and higher long-rwn inllation expectations. This means that there is less scope for short-run monetary policy. Britain's lowering of short interest rates have for instance resulted in substantial long-run inflation expectations, as documented in Bark of England's quarterly Inflation Ruport (Bank of England (1993)). 


\section{Sum up}

Let me end by summarizing my message in three points. Fixed exchange rates now seem much less effective as means to price stability than many of us thought before. Therefore, monetary stability and credibility has to be built at home with other means. A move to fexible exchange rates makes it no less essential for a price stability policy to build monetary credibility.

This should not be interpreted as an argument that flexible exchange rates are always to be peeferred to fixed exchange rate. There are other arguments than price stability for Exed exchange rates, for instance the reduction of relative price variability in order to promote trade, foreign direct investment and general economic integration. Fixed exchange rates may be a complement to monetary stability and credibility at home, as they appear to be for Austria and the Netherlands, although they are certainiy not a substitute. They are simply neither necessary nor sufficient for credible price stability. 


\section{References}

Bank of England (1993), In fation Report, August 1993.

Bernanke, Ben, and Frederic Mishkin, (1992), "Central Bank Behavior and the Strategy of Monetary Policy: Observations from Six Industrialized Countries, NBER Hacroeconomics Annual 1992, 183-228.

Bank for International Settlements (1993a), Central Bank Survey on Foreign Exchonge Market Activity in April 1992, Basle.

Bank for International Settlements (1993b), 63rd Annual Report 1992-1999, Basle. Committee of EC Governor's (1993), Anrual Report 1992.

Crockett, Andrew D., and Morris Goldstein (1976), "Inflation under Fixed and Flexible Exchange Rates," IMF Staff Popers 23, 509-544.

Eichengreen, Barry, and Charles Wyplosz (1993), "The Unstable EMS," Brookings Papers on Economic Activity, 1:1993, 51-143.

Flood, Robert P., and Peter M. Garber (1984), "Gold Monetization and Gold Discipline," Journat of Political Economy 92, 90-107.

Frankel, Jeffrey, and Steven Phillips (1991), "The European Monetary System: Credible at Last?", NBER Working Paper No. 3819.

Giavazzo, Francesco, and Luigi Spaventa (1990), "The 'New' EMS," in Paul De Grauwe and Licas Papademos, eds., The European Monetary System in the 1990s, Longman, London and New York.

Goldstein, Morris, David Folkerts-Landau, Peter Garber, Liliana Rojas-Suárez and Michael Speucer (1993), International Capital Markets. Part I. Exchange Rate Management and International Capital Flows, IMF.

Group of Ten (1993), International Capital Movements and Foreign Exchange Markets: A report to the Ministers and Governors by the Grotp of Deputies, Rome.

Hô̆rngren, Lars, and Hans Lindberg (1993), "The Struggle to Turn the Swedish Krona into a Hard Currency," Working Paper No. 8, Sveriges Riksbank. 
International Monetary Fund (1993), World Economic Outlook: Interim Assessment, January 1993.

Lehwussaari, Olli-Pekka, Antti Suvanto and Laura Vajanne (1993), "Cuzrency Band and Credibility: Finnish Experiences," Working Paper, Bank of Finland.

Lindberg, Hans, Pauł Sōderlind and Lars E.O. Svensson (1993), "Devaluation Expectations: The Swedish Krona 1982-1992," Economic Journal, forthcoming.

Miller, Marcus and Alan Sutherland (1991), "The 'Walters Critique' of the EMS - A Case of Inconsistent Expectations?," The Monchester School 59, Supplement, 23-37 June 1991.

Obstfeld, Maurice (1986), "Rational and Self-Fulfilling Balance-of-Payments Crises," American Economic Review 76, 72-81.

Portes, Richard (1993), "EMS and EMU After the Fall," Worid Economy 16, 1-15.

Rose, Andrew K., and Lars E.O. Svensson (1994), "European Exchange Rate Credibility Before the Fall," European Economic Review, forthcoming.

Sōderstzöm, Hans Tson (1993), "Finland's Economic Crisis," SNS Occasional Paper No. 47 , Stockholm.

Svensson, Lars E.O. (1993), "Assessing Target Zone Credibility: Mean Reversion and Devaluation Expectations in the ERM, 1979-1992," European Economic Revieu 37, $763-802$.

Walters, Alan (1986), Britain's Economic Renaissance, Oxdord University Press, Oxford. 

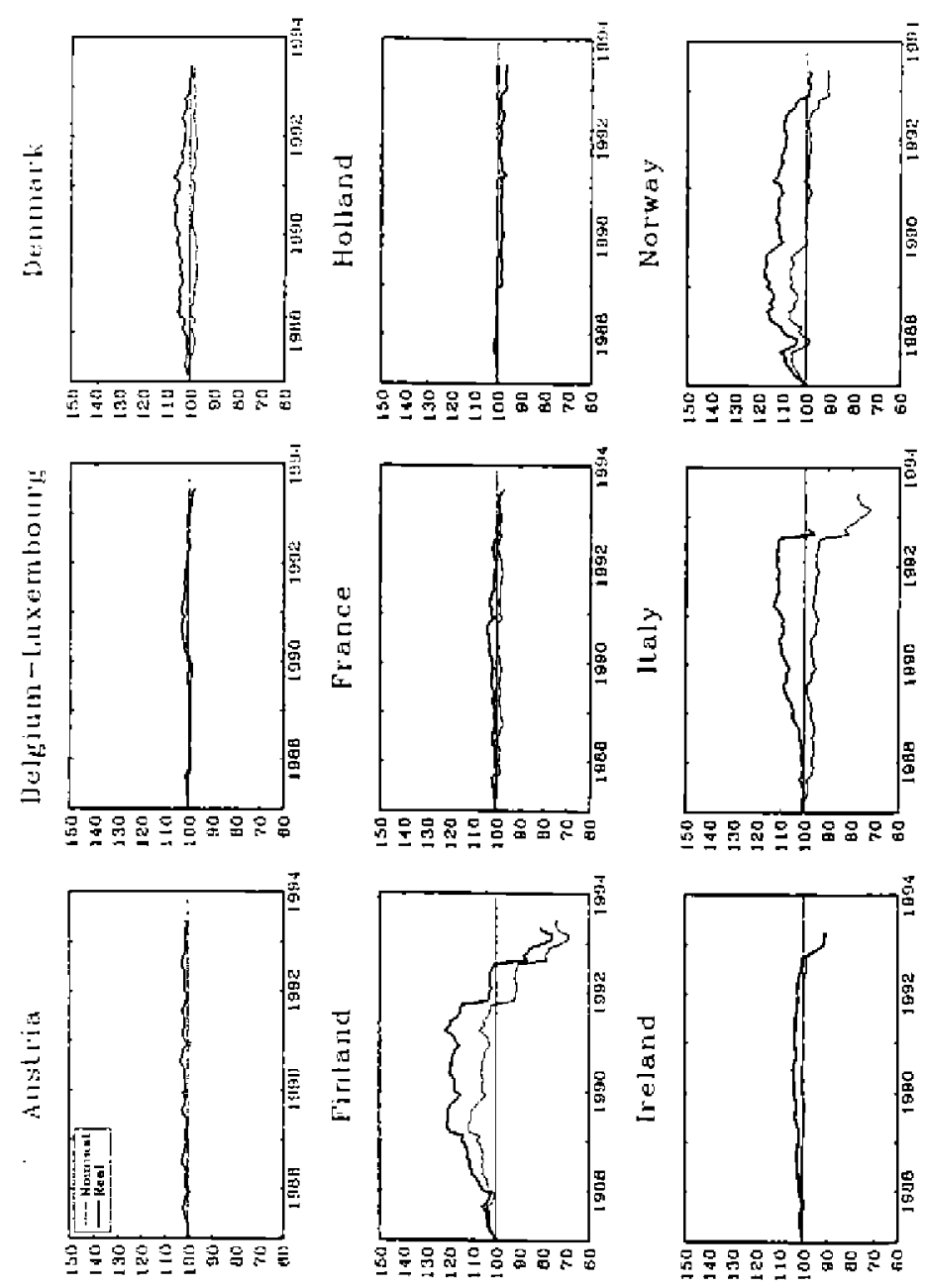

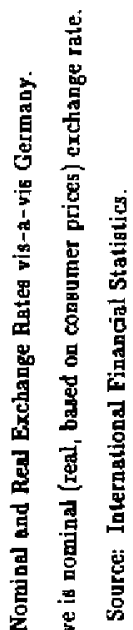

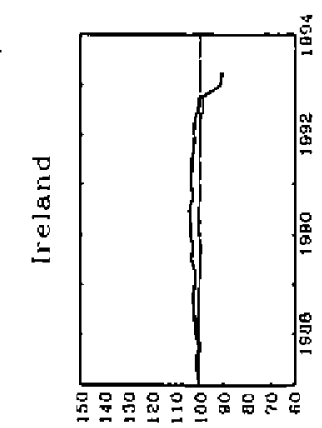



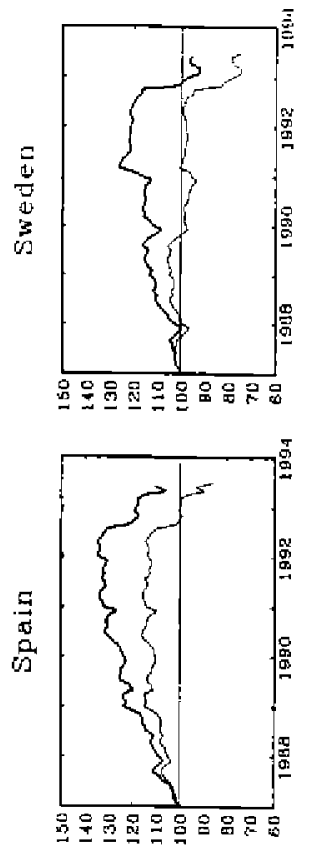

总
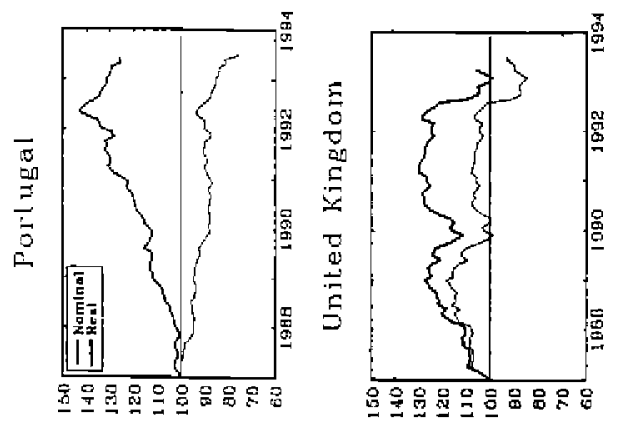


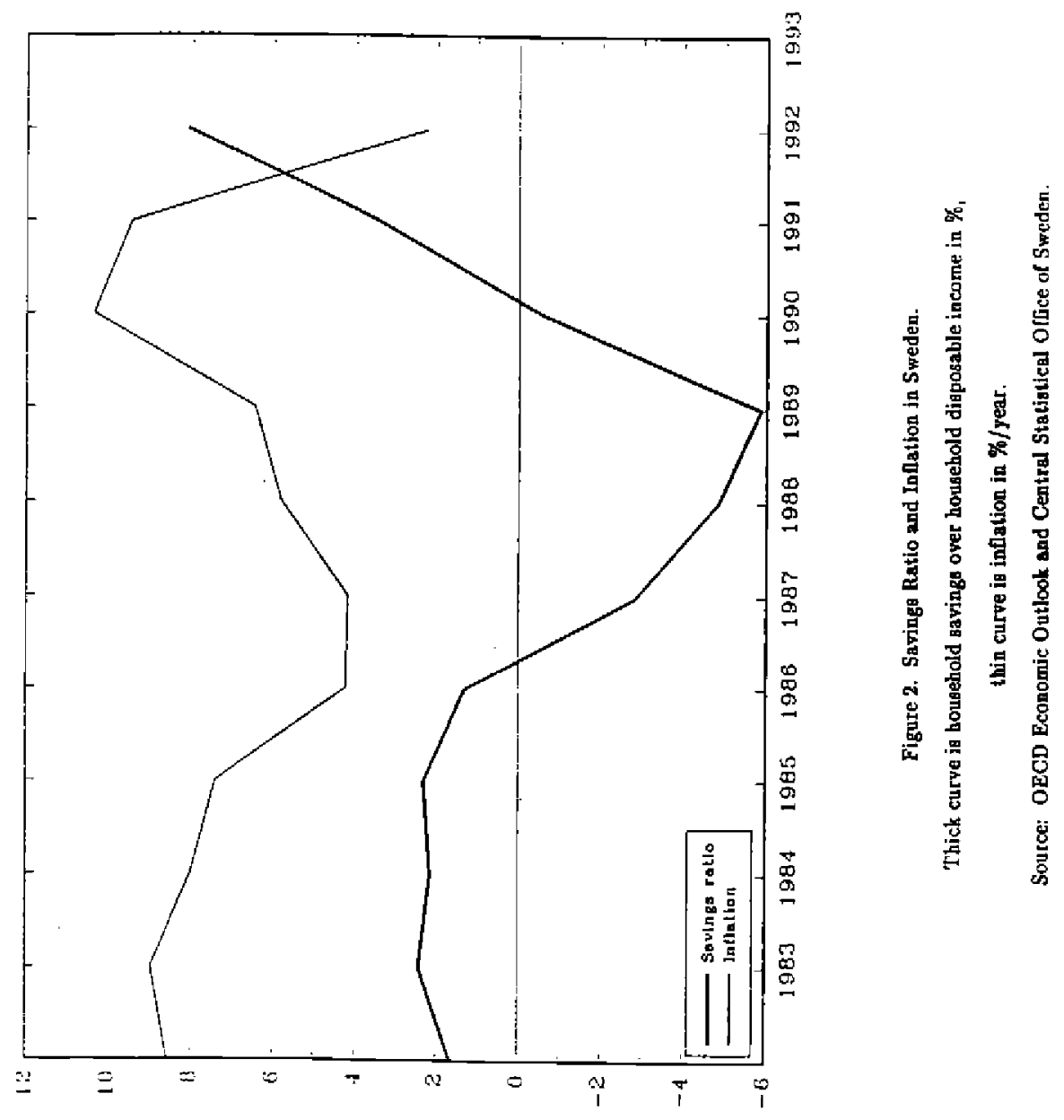



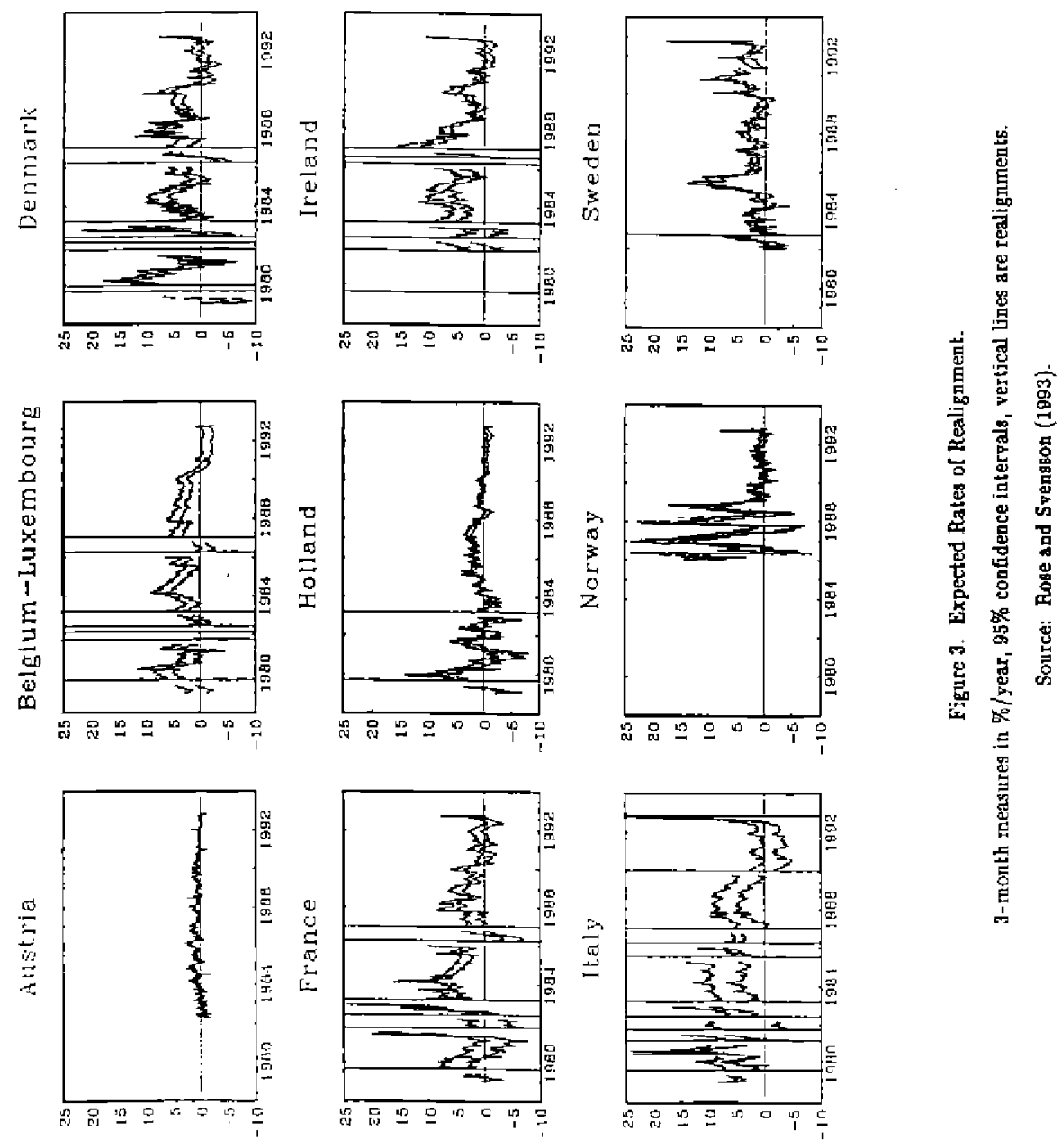

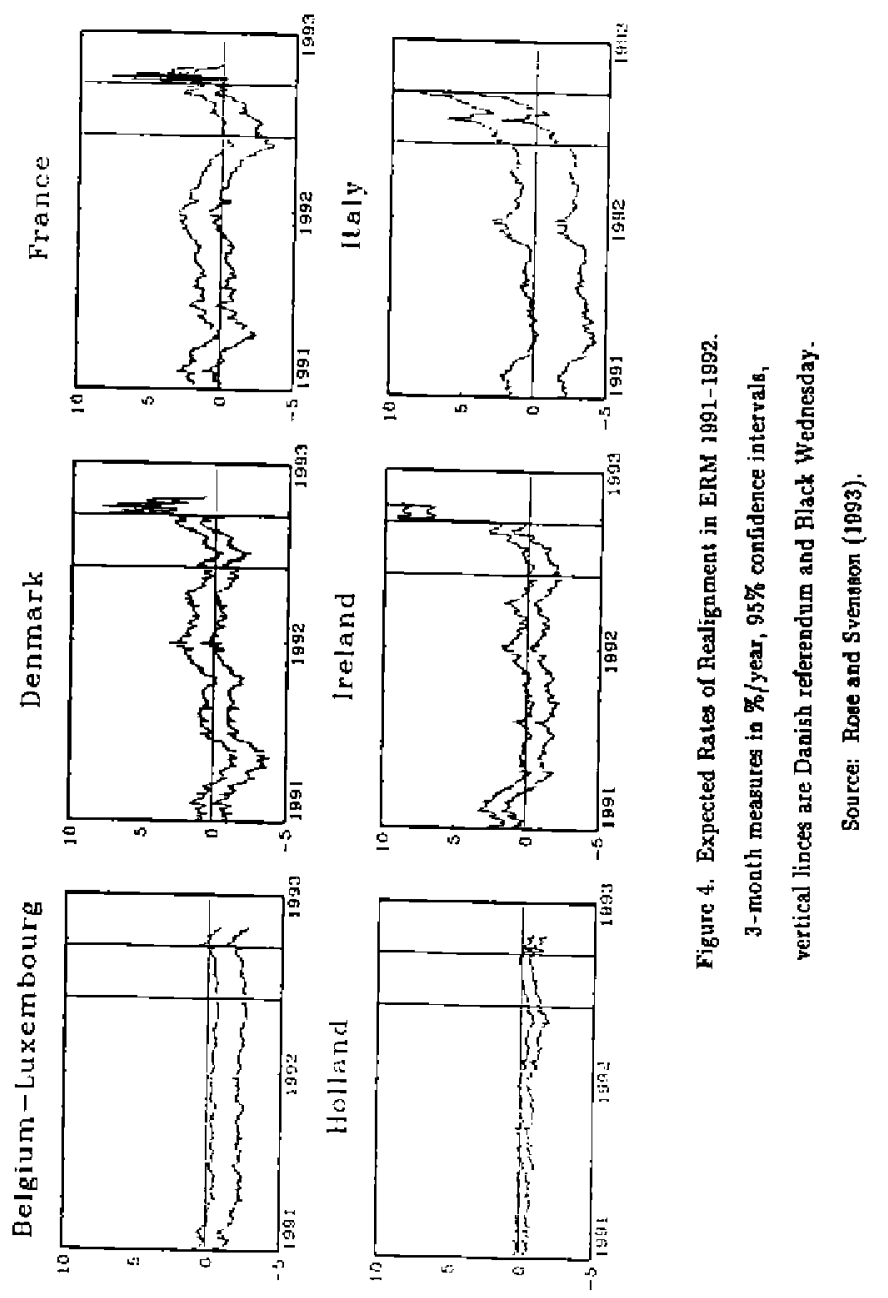


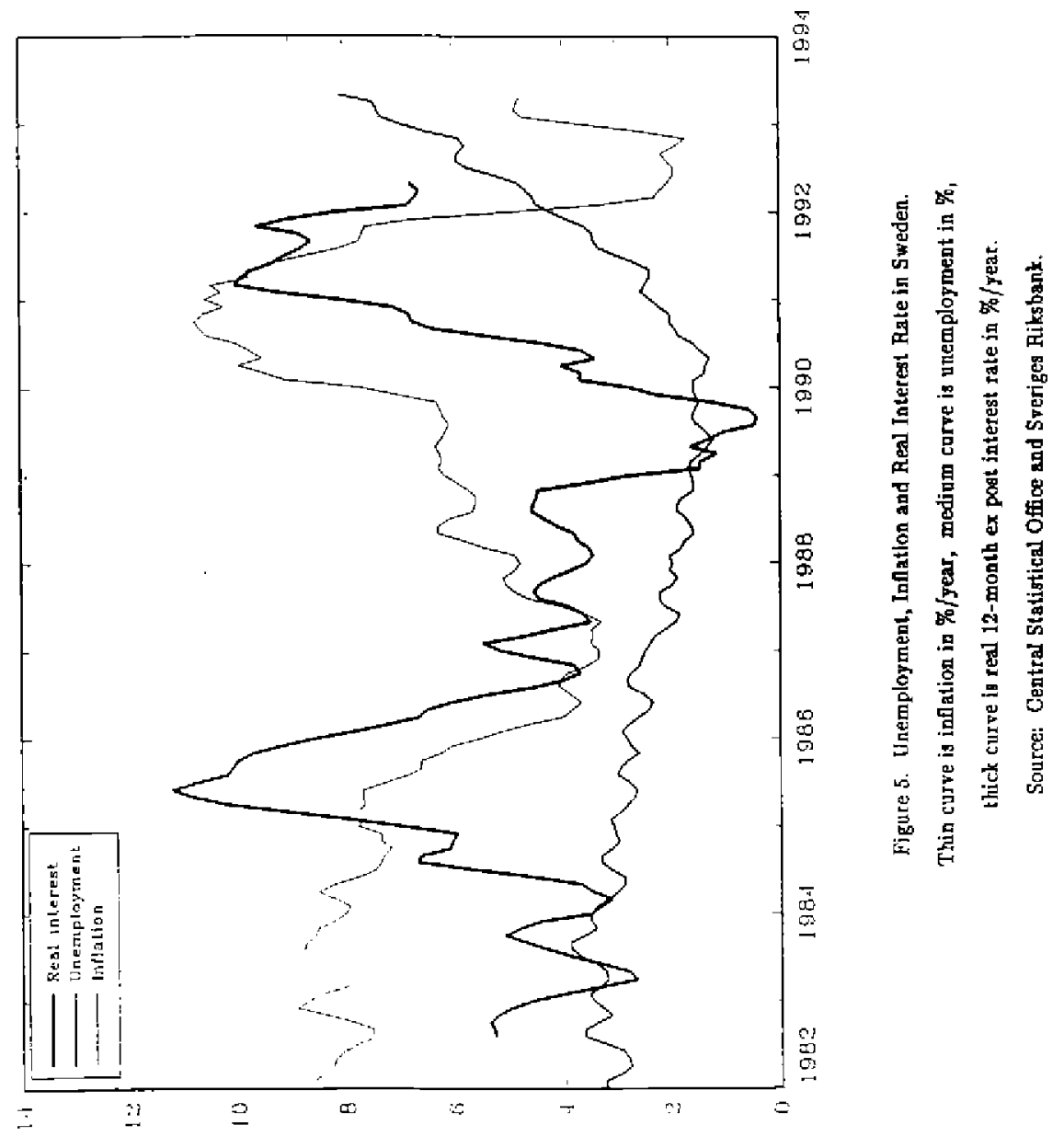

